James-Heineman Foundation, Hannover, and the Department of Zoology, University of Cambridge. I thank Sir Vincent Wigglesworth and Dr. J. W. L. Beament for making conditions so favourable for the work.

PaUl W. Winston*

Department of Zoology,

University of Cambridge.

* Present address: Department of Biology, University of Colorado, Boulder, Colorado.

'Lees, A. D., Parasitology, 37, 1 (1946).

2 Winston, P. W., and Nelson, V. E., J. Exp. Biol., 43, 257 (1965),

3 Beament, J. W. L., Biol. Rev., 36, 281 (1961).

4 Beament, J. W. L., Symp. Soc. Exp. Biol., 19, 273 (1965).

- Ramsay, J. A., and Brown, R. H. J., J. Sei. Instrum., 32, 372 (1955).

\section{Influence of Anti-rheumatic Drugs on Urinary Excretion of Hydroxyproline in Lathyrism}

LATHXROGENiC agents in the diet of several animal species induced an increase in the soluble collagen fractions present in various tissues, with a parallel increase in the hydroxyproline peptides excreted in the urine ${ }^{1-3}$. Simultaneous administration of hydrocortisone to rats on a diet of Lathyrus odoratus partially reduced the increased amount of neutral salt soluble collagen in skin ${ }^{4}$; although sodium salicylate was more effective than hydrocortisone. The present investigation was undertaken to ascertain whether the simultaneous treatment of lathyritic rats with anti-rheumatic drugs influenced the increased concentration of hydroxyproline in the urine.

Male Wistar rats, initial weight $50 \mathrm{~g}$, were placed on a diet containing 60 per cent sweet-pea seeds (Lathyrus odoratus). Control animals were fed standard Larsen diet. Anti-rheumatic drugs were administered simultaneously with the diet of $L$. odoratus in the following doses: $7.5 \mathrm{mg} / \mathrm{kg}$ of hydrocortisone intraperitoneally, $200 \mathrm{mg} / \mathrm{kg}$ of sodium salicylate intraperitoneally, 20 $\mathrm{mg} / \mathrm{kg}$ of chloroquine-diphosphate (Resochin-Bayer) intramuscularly; all were given daily for 6 days a week. An attempt was made to maintain the weights of animals so that they did not differ by more than 15 per cent. After a period of 35 days the urine collections were made during a $24 \mathrm{~h}$ period and urinary hydroxyproline determined by the method of Prockop and Udenfriend ${ }^{6}$.

Table 1. EXCRETION OF HYDROXXPROLINE IN CONTROL AND LATHYRITIC RATS TREATED WITH ANTI-RHEUMATIC DRUGS

\begin{tabular}{|c|c|c|c|c|}
\hline Treatment & Number & $\begin{array}{l}\text { Weight } \\
\text { of ani- } \\
\text { mals }(g)\end{array}$ & $\begin{array}{c}\text { Hydroxyproline } / 24 \mathrm{~h} \\
\text { ( } \mu \mathrm{g} \pm \text { standard } \\
\text { error })\end{array}$ & $P$ \\
\hline Control & 8 & 130 & $646 \cdot 1 \pm 138 \cdot 5$ & \\
\hline Hydrocortisone & 6 & 130 & $491 \cdot 4 \pm 156 \cdot 7$ & $0.05^{*}$ \\
\hline Sodium salicylate & 6 & 125 & $908 \cdot 6 \pm 42 \cdot 7$ & $0.01^{*}$ \\
\hline Chloroquine & 6 & 120 & $636 \cdot 6 \pm 146 \cdot 5$ & Insign. \\
\hline Lathyrus & 8 & 115 & $1,493 \cdot 5 \pm 262 \cdot 3$ & $0.01^{*}$ \\
\hline $\begin{array}{l}\text { Lathyrus }+ \\
\text { hydrocortisone }\end{array}$ & 6 & 125 & $1,265 \cdot 6 \pm 279 \cdot 5$ & $0.05-0.02 \dagger$ \\
\hline $\begin{array}{l}\text { Lathyrus + } \\
\text { sodium salicylate }\end{array}$ & 6 & 110 & $749 \cdot 2 \pm 93 \cdot 1$ & $0.01 \uparrow$ \\
\hline $\begin{array}{l}\text { Lathyrus + } \\
\text { chloroquine }\end{array}$ & 6 & 110 & $585 \cdot 2 \pm 133 \cdot 2$ & $0.01 \uparrow$ \\
\hline
\end{tabular}

Table 1 gives the results of this experiment. Lathyritic animals excreted more than twice as much hydroxyproline in a day as the control animals. The treatment with hydrocortisone in non-lathyritic animals decreased the amount of excreted hydroxyproline which is in agreement with the findings of Kivirikko et al. ${ }^{7}$. Chloroquine did not influence the excretion of hydroxyproline. Normal animals treated with sodium salicylate excreted more hydroxyproline in urine. The administration of any of the tested anti-rheumatic drugs to lathyritic animals resulted in a decrease of elevated amounts of urinary hydroxyproline. The normalization was complete in animals treated with chloroquine and sodium salicylate. In the group treated with hydrocortisone this decrease occurred to a lesser extent.
Results of Kühn et al. ${ }^{8}$ indicated that lathyrogenic agents increased the rate of collagen synthesis. It is possible that anti-rheumatic drugs have an effect on the amount of this newly synthesized collagen in lathyritic rats. This may be the case with corticoids which are claimed to oppose the synthesis of collagen and thus reduce the quantity of soluble collagen present in the body ${ }^{7}$. It is more difficult to explain the therapeutic effects of sodium salicylate and chloroquine because the former increased the amount of urinary hydroxyproline and the latter is known to increase the amount of soluble collagen in rat skin. Kühn et al. ${ }^{8}$ pointed out that increased synthesis of neutral salt soluble collagen in lathyritic rats is accompanied by a simultaneous increase in degradation of collagen. Lathyrogenic agents may activate tissue cathepsins ${ }^{9}$ which are capable of degrading soluble collagen, while anti-rheumatic drugs are known to inhibit certain proteolytic enzymes ${ }^{10}$. It is suggested that the action of anti-rheumatic drugs is to suppress proteolytic attack on the collagen which has been newly synthesized in lathyritic animals and, thus, reduce the concentration of urinary hydroxyproline in these animals.

\section{Z. TrRavská \\ K. TRNAVSKÝ}

Research Institute for Rheumatic Diseases,

Pieš̌any, Czechoslovakia.

${ }^{1}$ Martin, G. R., Mergenhagen, S. E., and Prockop, D. J., Nature, 191, 1008 (1961)

¿Jasin, H. E., and Ziff, M., Proc. Soc, Exp. Biol, Med., 110, 837 (1962).

${ }^{3}$ Orbison, J. L., McCrary, C., and Callahan, M., Amer. Med. Assoc., Arch. Pathol., 79, 292 (1965).

+ Trnavský, K., Trnavská, Z., and Cebecauer, L., Nature, 207, 993 (1965).

"Trnavský, K., Trnavská, Z., and Cebecauer, L., Med. Pharm. Exp., 13, 98 (1965).

${ }^{6}$ Prockop, D. J., and Udenfriend, S., Anal. Biochem., 1, 228 (1960).

${ }^{7}$ Kivirikko, K. I., Laitinen, O., Aer, J., and Halme, J., Biochem. Pharm., 14, 1445 (1965).

${ }^{8}$ Kühn, K., Durruti, M., Iwangoff, P., Hammerstein, F., Stecher, K., Holzmann, H., and Korting, G. W., Hoppe-Seyl. Z., Physiol. Chem., 336, 4 (1964).

${ }^{0}$ Tanzer, M. L., and Gross, J., J. Exp. Med., 119, 275 (1964).

${ }^{10}$ Domenjoz, R., and Mörsdorf, K., Proc. Intern. Symp. on Non-steroidal Anti-inflammatory Drugs, Milano (1964).

"Whitehouse, M. W., and Cowey, F. K., Biochem. J., 98, 11 P (1965).

\section{Oxygen Flux across the Environmental Interface of Teleost Cornea}

WHILE the use of oxygen directly from the environment by mammalian cornea was long suspected and had even been shown qualitatively, oxygen uptake by the human cornea in vivo has only recently been measured ${ }^{1-3}$.

A structure of considerable comparative interest in this regard is the fluid immersed, poikilothermic cornea of the fresh water teleost. The normal oxygen demand of this epithelium might be expected to be somewhat less than that for the mammalian due to the generally cooler environment and consequently lower metabolic rate.

To measure the oxygen uptake by this tissue directly from the environment a polarographic electrode of the 'Clark' type ${ }^{4}$ together with a 'Beckman Physiological Gas Analyser Model 160', and a potentiometric strip recorder were used. The reservoir from which the epithelial cells withdrew oxygen was a polyethylene sheet placed directly over the reducing electrode of the probe (25u diameter). The polyethylene membrane was separated from the platinum reducing electrode by a negligibly thin layer of $p \mathbf{H} 9$ borate buffer solution $(0.01 \text { molar in potassium choloride })^{5}$. For a membrane $12 \mu$ thick the amount of oxygen dissolved in the polyethylene at $155 \mathrm{~mm}$ of mercury partial pressure $\left(24^{\circ} \mathrm{C}\right)$ is $1.0 \times 10^{-5} \mathrm{ml} . / \mathrm{cm}^{2}$. The solubility of oxygen in polyethylene is not a sensitive function of temperature. Over the temperature range used here the solubility does not change more than 10 per cent ${ }^{6}$. Such change is considered negligible for the purposes of this study. The time constant of the system varied with temperature, but this was measured at each of the four 